\title{
Paul Ferstl
}

\section{Introduction: Dialogues between Media}

I introduce this volume with distinct pleasure, since it marks the final step in a journey that started seven years ago, at the ICLA 2013 at the Sorbonne. The decision to host the ICLA 2016 at the University of Vienna meant that, from 2013 to 2016, I had to face the biggest organizational challenge of my career, since I had the honour to support Achim Hölter, the chair of the organizing team, both as senior assistant and as ICLA 2016 program coordinator and editor. The realization of the congress, strenuous as it was, has since then filled me with a very satisfying sense of achievement, and not just a little pride. I would like to take this opportunity to sincerely thank my senior assistant colleague, Constanze Prasek, whose contribution to the success of this event cannot be overstated. The same applies to our numerous student volunteers.

As program coordinator, it was my responsibility to arrange slots and venues for 1,895 presentations and meetings. On Friday, July 22nd 2016, we started the general program at 9 A.M. in 44 parallel sessions. Another part of my job was communicating the program of the congress via a database, online documents, and a printed program. Weighing a total of 1681 kilograms, the printed programs mercifully arrived in time to be distributed to the individual welcome bags our guests received on arrival. This print program, however diligently prepared, ceased to provide a $100 \%$ correct outline of the envisaged event the moment it was sent out to the printers. Cancellations, due to illness or political unrest, were of course bound to keep the program in constant flux, and although the organizing team did its best to keep the online program up to date, and to communicate the changes to the congress participants via displays on various screens on the premises, it was impossible to keep track of all changes, comings and goings. During my preparations for this introduction, I looked at the various artifacts that document the ICLA 2016. It is quite an astonishing array of media: minutiae of meetings, protocols, calls for papers, e-mail negotiations with authorities, caterers, printers, publishing houses, abstracts from scholars around the globe, peer review reports, the program database, the print file of the programs, the printed program, accounts of conference fees paid, photographs, video and sound recordings of round tables and other events, social media coverage, and so on. The vision of the congress and the building of its infrastructure are well documented, the accounting has been settled and cleared, but the event per se, all these hundreds of presentations, the bustle of the two thousand people who congregated in the University of Vienna for a summer week, remains wonderfully intangible. The organizing team tried to represent and document the action on various media, and the course of the 
event at least implies that we succeeded in providing a structure to facilitate its execution. Whether a certain presentation definitely took place, however, only those know for sure who actually participated in it. Before the congress, I had read every participant's name and the title of every presentation on the program several times, and had allocated a room and a time slot to each event, meaning I was quite well acquainted with the program; but when it was all over I realized that, since behind-the-scenes duties had kept me busy, I had only attended two panels in person, and these only because I had been present because of on-site responsibilities anyway.

It may be stating the obvious to say that every participant in the ICLA 2016 experienced the event in a singular, individual way; still, doing so certainly draws attention to the interesting question of how, by what means, we may document these experiences in order to share them, to provide the basis for their sound comparison and further processing. At first, there is the idea of the event, the planning and its numerous manifestations of different states of preparation; then the event itself actually takes place, in the fleeting experience of a moment, the participation in performance; afterwards, tradition asks for a tangible object in the form of congress proceedings, preferably as a bound print volume, while innovation also asks for an open-access online format. Whether on paper in your hands or on your screen, this volume brings to you some results of the congress. The reflections on the shape of these ICLA 2016 proceedings and the underlying concept have already been sufficiently elucidated in the introduction of Volume I. Both organizers of group sessions and presenters of single papers were cordially invited to contribute, either by providing collections of articles, or by submitting single papers for peer review. I am very grateful to Mag. Sophie Mayr, Hannah Schroder, M.A., and Dr. Juliane Werner for the expertise, time and effort they employed in the gathering and processing of the resulting submissions.

It is now my honour to introduce Volume V of the ICLA 2016 proceedings, entitled Dialogues between Media, which presents texts that deal with the interplay of media or inter-arts studies, as well as papers with a focus on comics studies. The latter is mainly due to the inclusion of an ICLA 2016 group session on comics studies, though additional three articles within this volume from beyond that source reference comics and thus are further testimony to the fact that comics have truly arrived in mainstream academic discourse. As to be expected, adaptation is a key term for the studies presented in this volume; various articles discuss the adaptation of literary source texts in different target media, with cinematic versions (6) most prominent, followed by comics adaptations (4), TV series (2), theatre (1), and opera (1). Beyond adaptation, three additional papers address the relationship of literary text and image, in the form of inspiration by national cultural iconography, the image as literary topos, or in the form of illustration. 
Papers on electronic literature, a multimedia art project, an online science portal, a Brazilian Volkswagen advertisement, and a comparison of hip hop and Ancient Greek poetry further show the range of this volume, and many of the strands that are woven into dialogues between media. The performing arts beyond theatre and music, however, are conspicuously absent, as is (computer or other) gaming, and much of the online world; and attention to those media beyond the arts that constitute and regulate our interactions in everyday life is quite scarce. These absences may have many reasons - a respective relative medial applicability for discourse rooted within comparative literature, the relevance of trends and valuations within our discipline, or the time necessary to digest new developments in our world. Still, one has to remember that this volume contains only a part of the ICLA 2016 presentations, and there were many that would have complemented this collection well by opening up ways into new worlds, such as that of gaming.

Among these group sessions that are not included in this volume, I would like to mention “Do you speak digital?” organized by Hans-Joachim Backe (IT University of Copenhagen), "Intermedialität: Konzeptionalisierungen und Methoden" by Anke Bosse (Universität Klagenfurt) and Claude Paul (Universität Mannheim), "Comparison and Intermediality: The Gesamtkunstwerk" by Caroline Fischer (Université de Pau), Massimo Fusillo (University of L’Aquila), and Marina Grishakova (University of Tartu), “One Theme: Different Media” by Thaïs Flores Nogueira Diniz (Universidade Federal de Minas Gerais, Belo Horizonte, Brazil), "Pictures for Everybody! Postcards and Literature/Bilder für alle! Postkarten und Literatur" by Simone Sauer-Kretschmer (Ruhr-Universität Bochum) (published as "Jahresband” of „Sprachkunst“: Postkarten und Literatur, Beiträge zur Literaturwissenschaft. Verlag der Österreichischen Akademie der Wissenschaften. XLVIII/2017), "The Serialization of Literature and the Arts" by Markus Schleich (Universität des Saarlandes) and Jonas Nesselhauf (Universität Vechta), "Media, Mediation, Fiction” by Benoît Tane (LLA CREATIS, Université de Toulouse Jean-Jaurès) and Isabelle Krzywkowski (Université Grenoble 3-Stendhal, Saint-Martin-d’Hères), and "Die vielen 'Sprachen' der Klassiker” by Paula Wojcik (Universität Wien) and Sophie Picard (Friedrich-Schiller-Universität Jena) (published as: Klassik als kulturelle Praxis: Funktional, intermedial, transkulturell (spectrum Literaturwissenschaft / spectrum Literature, Band 62), edited by Paula Wojcik, Stefan Matuschek, Sophie Picard, Monika Wolting).

Five ICLA 2016 group sessions have contributed collections of articles to this volume: "Unsettled Narratives: Graphic Novel and Comics Studies in the 21st Century”, organized by Lea Pao (Pennsylvania State University), Stefan Buchen- 
berger (Kanagawa University, Yohohama), Kai Mikkonen (University of Helsinki), and David Coughlan (University of Limerick); "Hybridisierung literarischer Sprachen und Ausdrucksformen als Innovationsmodus” (Franz Hintereder-Emde, Yamaguchi University); "Languages of the Imaginary” (Sandra Trabucco Valenzuela (Universidade Anhembi Morumbi, São Paulo, Brazil), Maria Zilda Cunha (Universidade de São Paulo, São Paulo, Brazil), Maria Auxiliadora Baseio (Universidade Santo Amaro, São Paulo, Brazil); “The State of Adaptation Studies Today“, organized by Brigitte Le Juez (Dublin City University, Dublin, Ireland), César Domínguez (University of Santiago de Compostela, Santiago de Compostela, Spain); and "Foreign Literatures in Web 3.0", organized by Silvia Ulrich (Università degli Studi di Torino). Since the latter only consists of two papers, I have taken the liberty to include it in the section "International Intermediality", in which I have collected the papers individual authors have contributed to this volume.

The volume opens with the collection of articles submitted by the ICLA Research Committee on Comics Studies and Graphic Narrative. Stefan Buchenberger and Kai Mikkonen outline the development of the research committee from informal conference-room conversations at the Hong Kong ICLA World Congress in 2004 to its official recognition as the ICLA Research Committee on Comics Studies and Graphic Narrative in 2015, along with a short discussion of the general international transformation of comics studies into a respected, established research field. In "Unsettled Narratives: Graphic Novel and Comics Studies in the Twenty-First Century - A Preface”, Angelo Piepoli, Lisa DeTora, and Umberto Rossi describe the reception of comics in the twentieth and twenty-first centuries, from their widespread rejection by the cultural establishment to their acceptance by the mainstream acceptance and their academic reevaluation. In "Future Imperfect: Dystopia, Time Travel, Absolute Power, and the Incredible Hulk", Stefan Buchenberger analyzes a 1990s addition to the Incredible Hulk canon in which traditional science-fiction plot elements such as a dystopian future and time travel are employed to give a new twist to the eternal struggle between the Incredible Hulk and his alter ego, Bruce Banner. Nicola Paladin's "The Participation of Will Eisner's The Spirit in World War II" focuses on the historical context of one of the first models for the superhero tradition in the USA and argues that a strong anti-Nazi feeling, as well as pro-American intervention propaganda, constitutes a recurrent subtext throughout the adventures of the Spirit. In "Social Control and Closed Worlds in Manga and Anime”, Francesco Ursini shows how closed and controlled worlds double as settings and themes that allow authors to develop immersive narratives, discussing four manga (Blame!, Nijūseiki Shōnen, Btooom!, and 
Yakusoku no Neverland) and three anime movies (Shōjo Kakumei Utena, Ergo Proxy, and Texhnolyze). The theme of war in a national tradition is of central interest in Umberto Rossi's “The Myth of the Great War: Hugo Pratt's World War I Graphic Novel and Stories”. Examining seven graphic narratives by Pratt, the article reads these narratives in connection with the myth of the Great War as it was defined by the Italian historian and literary critic Isnenghi in 1970 in his groundbreaking monograph Il mito della grande guerra, but also shows these graphic narratives present readers with a bewildering mix of historical/quasi-historical characters, real and imaginary places, often establishing surprising and complex intertextual short-circuits that connect Pratt's World War I narratives, history, and the historical imagination. Denise Ask Nunes' “The Toxic Heroine in Nausicaä of the Valley of the Wind" discusses interlinked concepts of ecology and heroism, new materialism, and non-human agency and their influence on our ideas of morality and consequently heroism. Barbara Grüning compares different public uses of comics to represent difficult pasts: "Educating to Remember: The Public Use of Comics in Germany and Italy" combines four case studies (the National Socialist and GDR pasts in the German memory field, and the Fascist past and terrorist/Mafia massacres in the Italian memory field) to focus on the narratives and aesthetic forms culturally legitimized in the two national public memory spaces, the cultural frames which define a specific past, and the cultural paradigms of transnational comics, thus highlighting the social actors involved in this process of collectively working memory. Angelo Piepoli's “Gender Gaps in the Clouds: Expressive Repression and Signs of Change in Italian Comics of the 1950s and 1960s" focuses on the change to the gender gap in the history of Italian comics as a sign of social change in Italy. In "Visualizing the Gothic in Neil Gaiman's The Graveyard Book and Its Illustrated Adaptations", Alison Halsall argues that Neil Gaiman's appropriation of the Gothic topos in The Graveyard Book (2008) deliberately unsettles its genre and that P. Craig Russell's graphic novel version (2014) further develops the hybridity of Gaiman's source text in more depth. Lisa DeTora suggests in “The Quantum Gaze as a Model for Simultaneous Mobilization in Graphic Narrative” that graphic narratives require different modes of looking relations when compared with the fixed, linear, and sequential and time-constrained visual system of film. Angelo Piepoli closes this section with a further contribution ("Wordless: Interpreting Visual Sequence as Storytelling: Towards a Semiotic-Textological Approach to Comics and Pictorial Narrative without Verbal Components”), employing János Sándor Petőfi's semiotic textology to incorporate textological concepts such as connexity, cohesion, constringency, and coherence in the study of comics.

Franz Hintereder-Emde introduces the section stemming from the panel he organized at the congress, "Hybridization as a Mode of Innovation", with a brief look at the notion of hybridity while focusing on the works of Robert Walser, a 
Swiss author who made the combination of literary genres, association, and arabesque description a key technique of his writing. Michel de Boissieu follows with "Goethes Faust in Oper, Film und Manga: Die Faust-Bearbeitungen bei Gounod, Murnau und Tezuka am Beispiel der Studierzimmer-Szene”, highlighting the influence of the respective target medium on the adaptive process. Marie-Christine Gay’s “'Gossen-Orpheus’ Jean Genet: deutsche Übersetzungs- und Rezeptionsschwierigkeiten eines poetisch-derben Stils" traces the reception of Jean Genet in West Germany, where his hybrid, often provocative style led to considerable difficulties in translation as well as fierce debates about the reception of this "gutter Orpheus". The critical comparison between the original and German versions sheds new light on the difficulty of transposition and ultimately intercultural communication. The need for adaptation, the interventions during the production process as well as the reception by the German public are highly relevant to understanding the power and limits of hybridization as an innovative process. "Grimm 2.0 - Die Brüder Grimm in der Postmoderne" by Timon Jakli examines the ABC television series "Once upon a Time" by Kitsis/Horowitz and the comic book franchise "Fables" by Bill Willingham et al. Both adaptations make use of the serialized storytelling to weave a web of interconnected narratives from different sources (the brothers Grimm, Eastern fables, present-day pop culture), combining subtexts and backgrounds of tales and figures to create new meaning; irony and play with citations create a multi-layered narrative universe with almost infinite cultural and literary references. Fuminari Niimoto’s “'das junge jakobli läßt den alten jakob grüßen' - Poetik im dazwischen der Sprachen und jenseits der Sprache in Friedrich Glausers Kriminalroman Die Fieberkurve” contrasts Glauser's detective novel Fever (1938) with its adaptation as radio drama (1990) in order to highlight Glauser's strategy to reveal multiple identities and moreover to unveil and cherish the differences in every single individual, beyond the the ostensible primary purpose to present a mystery story. Monika Schmitz-Emans focuses on comics and adaptation as well - "Dante-Comics zwischen Kanon- und Populärkultur: Spielformen der Hybridisierung und Strategien der Selbstreferenz" demonstrates that comics based on Dante and his Commedia show two main tendencies, either the simplification of the complex work for literary beginners, or the subtle reflection of and challenging response to that complexity through specific features of graphic and pictorial media. Friederike Schwabel highlights interactions between literature and popular music in "Intermediale Formen der Sebald-Rezeption in der populären Musik". She analyzes the reception of literary texts by W. G. Sebald in connection with a poetry reading by Patti Smith, a soundtrack by The Caretaker, and a song by the Sleeping States - varied forms of intermediality as well as their inter- and extracompositional functions can be made visible and discussed based on typologies by Werner Wolf. Arata Takeda's 
"Darstellung und Zeitlichkeit. Zu Gotthold Ephraim Lessings gattungstheoretischem Vermächtnis" traces the origin of Goethe's and Schiller's contention ("On Epic and Dramatic Poetry” (1797/1827)) that the essential difference between epic and dramatic poetry consists in the difference of their respective representation of time. Megumi Wakabayashi ("Schulromane von Robert Walser und Natsume Sōseki: Hybride Darstellungsformen zwischen 'hoch und niedrig”") presents the second examination of Robert Walser within this section, comparing his school novel Jakob von Gunten (1909) with Natsume Sōseki's school novel Botchan [The Fool from Tokyo] (1906), highlighting how Walser and Sōseki both criticized educational institutions as instruments for manipulation of public opinion in times of militaristic nationalism while succeeding in subverting the binary opposition between "high and low" literature. This section on hybridization concludes with Martina Zerovnik's “Wie hältst du's mit der Liebe? Vampirische Emanzipation im Abendlicht von Elfriede Jelineks 'Krankheit oder Moderne Frauen”'. The article reads Elfriede Jelinek's play Illness or Modern Women (1987) along with one of the text's main references, the novella Carmilla, and reflects on how love affects the personality and sphere of action of the characters within a patriarchal system.

The section "Languages of the Imaginary" is opened by Andia Abaï-Ringgenberg's and Patrick Ringgenberg's "La lumière dans les romans arthuriens et le Livre des rois de Ferdowsi”, a comparative study of the literary, esthetic and symbolic employment of light in medieval Western chivalric romances (twelfth and thirteenth century) and Iranian epic poetry from the beginning of the eleventh century. In "Temporality and Finitude: The Wolf in the Fiction of João Guimarães Rosa and of Marcus Aurelius Pimenta and José Roberto Torero”, Fabiana Corrêa Prando explores the symbol of the wolf in João Guimarães Rosa's Fita verde no cabelo [Green Ribbon in the Hair] and José Roberto Torero's and Marcus Aurelius Pimenta's Chapeuzinho Preto [Little Black Riding Hood]. Giovanna Gobbi Alves Araújo explores the aspect of visuality in A Cachoeira de Paulo Afonso [The Paulo Afonso Falls] by Castro Alves (1876) from the perspective of its dialogue with the pictorial and political construct of the Paulo Afonso Falls in the Brazilian collective imagination of the nineteenth century. Sandra Trabucco Valenzuela, Maria Auxiliadora Fontana Baseio, and Maria Zilda da Cunha analyze the adaptation of fairy tales in the TV series Once upon a Time in "Once upon a Time and So Many Other Times: Hansel and Gretel”. Sandra Trabucco Valenzuela’s and Luciane Ferreira Bonaldo's “Storytelling in Advertising: The Case of Os Últimos Desejos da Kombi” focuses on a Volkswagen do Brazil's advertising video produced in 2014 Os Últimos Desejos da Kombi [Kombi: Last Wishes] - which sought to appeal to or create memories in order to strengthen or establish affective ties with consumers.

The section "The State of Adaptation Studies Today" opens with Adile Aslan Almond "Adapting Hamlet to the Turkish Screen" which examines the only 
Turkish cinematic adaptation of Hamlet to date (Kadın Hamlet: Intikam Meleği [Lady Hamlet: The Angel of Vengeance] (1976)) within a wider historical context of Turkish Hamlets that have been adapted, staged, and produced in different genres and media with the modernizing aims of the Kemalist state in mind. Bernard Franco analyzes three cinematic adaptations of Bram Stoker's Dracula by Friedrich Murnau, Tod Browning, and Francis Ford Coppola, while Jia Guo examines Zhang Yimou's adaptation of Yu Hua's To Live. Brigitte Le Juez' “Modern Film Adaptations of Fairy Tales: An Examination of Four 2012 Versions of Snow White" discusses the transformative quality of adaptation (thus influencing the reception of the original source text) by examining four 2012 cinematic adaptations of Snow White: Tarsem Singh's Mirror Mirror, Rupert Sanders's Snow White and the Huntsman, Pablo Berger's Blancanieves, and Siegrid Alnoy's Miroir mon amour. In "Transnational Adaptations: The Nineteenth-Century Novel Revisited through a Transcultural Lens”, Margarida Esteves Pereira addresses issues of adaptation from the point of view of transcultural and transhistorical film adaptations of classic nineteenth-century realist novels.

As stated above, the section "International intermediality" presents two papers from the group session "Foreign Literatures in Web 3.0", followed by papers individual authors have contributed to this volume. In "Marlene Creates: Land, Nature, and the Forest as Poetry/Museum”, Carmen Concilio scrutinizes a Web project by the Canadian poet, land artist, and photographer Marlene Creates, A Virtual Walk of the Boreal Poetry Garden (2005), in order to assess the variety of media, forms, languages, and stances that this Web project displays to its both real and virtual audiences, also taking into consideration the existing corpus of art and literary criticism on the artist's career. Eleonora Marzi's "Entre linéarité et causalité : les caractéristiques de l'hypertexte dans la littérature numérique” discusses electronic literature, based on Michael Joyce's Afternoon, a Story, and Stuart Moulthrop's Victory Garden, arguing that the singularity of the hypertext, composed of hypertext links and nodes, has a narrative structure which differs from that of the paper format. In "Polyphonie. Mehrsprachigkeit_Kreativität_Schreiben: Projekt, Portal, Community. Wie viel Web 2.0 braucht ein wissenschaftliches Webportal?”, Michaela Bürger-Koftis, Ramona Pellegrino, and Sandra Vlasta discuss the potential and limitations of scientific web portals in a web 2.0 context. Beatrice Nickel's “Intertextualität als Intermedialität: Zum Mond fliegen mit Jules Verne, Georges Méliès, Brian Selznick und Martin Scorsese” presents intermediality as a form of intertextuality by applying Julia Kristeva's extended concept of textuality within the framework of a comparative case study by analyzing the influence of Jules Verne's moon-fiction Autour de la lune (1869) on Georges Méliès's silent film Le Voyage dans la Lune (1902), which has in turn affected Brian Selznick's best-selling novel The Invention of Hugo Cabret (2007) 
adapted by Martin Scorsese in his 3D-movie Hugo (2011). Irina Rosenau examines the relationship between text and image in Marc Chagall's Ma vie, 1921-1931. Christian van der Steeg's "Pallenberg alias Schwejk. Ikonografie der Satire, 19181933” analyzes the journalistic and literary reception of the 1928 Piscator theatre adaptation of Jaroslav Hašek's satirical novel Die Abenteuer des braven Soldaten Schwejk (1926). A comparison of two different oral traditions is presented in Blaž Zabel's “Archaic Greek Poetry and Hip-Hop: A Comparison”, which considers how research in hip hop scholarship could contribute to knowledge of archaic Greek poetry, with an emphasis on rhythm or flow, and intertextuality. Ramona L. Ceciu argues in "Language and Intermedial Metamorphoses in Indian Literature and Arts” that in multilingual cultures, transactions between language, culture, and the arts require a constant multiperspectivism as well as new enquiries that need to constantly alter language itself and its processes of intermedial transference into new, evolving literary/artistic idioms. "Intertextual Encounters between Jorge de Sena and Manuel Bandeira” by Dora Nunes Gago analyzes the echoes of the modernist Brazilian poet Manuel Bandeira in the poetry of the Portuguese writer Jorge de Sena. Alexander Vladimirovich Kalashnikov's "References to Music in the Translations of Alice's Adventures in Wonderland into Russian" is based on three Russian translations containing thirteen cases of musical references. Giovanna Corrêa Lucci analyzes the reimagining of the novel Emma, translated into another context, in "Emma/Juremma: An Intersemiotic Translation of Jane Austen's Emma into Brazilian Culture”. Ana Maria Machado’s “Literature and Cinema: The Military vs the People in the Hetero-Visiotypes and Hetero-Imagotypes of the 1974 Portuguese Revolution" focuses on the implications of different media and codes in the images of the Portuguese 25 April Revolution in the Luso-French-Brazilian Sérgio Tréfaut's documentary Outro país (2000) and Lídia Jorge's recent novel Os memoráveis (2014). Nilce M. Pereira examines book illustration from the perspective of translation studies, as intersemiotic translation exemplified by illustrations in three novels of Charles Dickens ("Translational Functions of Book Illustrations, and What Dickens Has to Do with Them”). Márcia Arbex' and Izabela Baptista do Lago's “Images littéraires de l'atelier de l'artiste” explore the literary topos of the studio in nineteenth- and twentieth-century French literature. Capucine Echiffre focuses on Blaze de Bury's reflections on the influence of the German Lied on French literature in the 1840s ("La conception française du lyrisme à l'épreuve du lied : l'exemple de Blaze de Bury”). 
